\title{
From the centre to periphery: The Middle Eastern impacts on Islamic education in Indonesia
}

\author{
Pradana Boy ZTF \\ Faculty of Islamic Studies, Muhammadiyah University of Malang, Indonesia \\ Email: fata.failasufa@gmail.com
}

\begin{abstract}
This paper traces Middle Eastern elements in Islamic education in Indonesia by looking at their institutions, curricula, method of teaching, orientations, and Islamic ideological transmission. The information on values and impacts of Indonesian and Middle Eastern Islam takes a one-way traffic pattern in general terms. The dynamics of Islam in Middle Eastern regions will fundamentally affect the practice and dynamic of Islam in Indonesia. This paper maps out Middle Eastern components' influence on the course of education run by these two largest Islamic organizations in Indonesia, Muhammadiyah and Nahdlatul Ulama'. However, following the New Order's fall, many Islamic groups emerged; education offered by these new groups and orientations is also worthy of evaluation. In the modernist group, the idea and practice of Islamic reform, which constitutes one of its significant agendas, mostly echoed the similar and earlier movements in the Middle East. Similarly, traditionalist groups are often described as the revivers of more locally-rooted Islamic practice, and therefore, they tend to blend local and Middle Eastern elements within their religious way.
\end{abstract}

Keywords: Middle East, Islamic Education in Indonesia, Islamic Organizations, Indonesian Islam 


\section{Introduction}

As Islam is originated from the Middle East, the influence of Middle Eastern elements on the practice of Indonesian Islam is undebated. In general term, the transmission of values, tradition and impacts of Middle Eastern Islam to Indonesia takes a one-way traffic pattern. This means that the dynamics of Islam in the Middle East will bring fundamental impacts to the practices and dynamic of Islam in the Indonesian archipelago. In contrast, it is rarely the case that dynamics and values of Indonesian Islam could be transmitted to the Middle East regions. The relationship of these two entities of Islam is often described as the relationship of "centre" and "periphery"; or in other expression, the relationship of "great tradition" and "little tradition". This influence is not confined to certain fields, but can be found almost in all walks of life. In such a case, the establishment of Islamic education is not an exception.

In the light of this context, this article is an investigation of the extent to which Middle Eastern elements shaped the establishment of Islamic educational institutions in Indonesia. Following generally-accepted categorization of Indonesian Islam into modernist and traditionalist Muslim groups as broadly represented by Muhammadiyah and Nahdlatul Ulama' respectively, this article maps out the influence of Middle Eastern components on the practice of education run by these two largest Islamic organizations. Furthermore, as in the post-New Order period many other Islamic groups emerged, which at the same time also enriched the competing orientations of Islamic groups. In this case, education offered by new groups and orientations are also worthy for evaluation.

In the case of modernist group, it can be asserted that the idea and practice of Islamic reform which constitute one of its major agendas mostly echoed the similar and earlier movements took place in the Middle East. In this case, it is interesting to investigate whether this echoing movement also impact the practice of Islamic education run by modernist groups or not. Similarly, traditionalist group is often described as the reviver of more locally-rooted practices of Islam, and therefore, it has a tendency to blend local and foreign (Middle Eastern) elements within their religious practices. An important question is whether the pattern is also mirrored in their educational system or it may take different form from its main orientation? Not less important are Islamic groups which completely mirror Middle Eastern Islam such as Hizbut Tahrir, Ikhwanul Muslimin, and many groups categorized as Salafi. These groups have also established their educational institutions which are much more Arabized than other groups' establishment. 
In general, this article will trace the influence of Middle Eastern elements in Islamic education in Indonesia by looking at their institutions, curricula, method of teaching, orientations, and Islamic ideological transmission.

\section{Literature Review}

\section{The Nature of Indonesian Islam}

Before moving further, it is important to outline some notes on recent development of Indonesian Islam and ideologies they adhere as well as how these ideologies impact their position within larger context of Islamic education in the country. By and large, forms and orientations of Islamic education in Indonesia are dependent on ideologies of groups which run certain types of education. In other words, the role of ideology in shaping models, types and orientations of education is almost uncontested. Theoretically speaking, ideology is a highly controversial concept, and it constitutes one of "most complex" concepts in social sciences (McLellan, 2013).Therefore, it has been widely defined and conceptualized with a possibility of overlaped and even contradictory definitions.

However, among most popular definitions is that ideology is seen as "the process of production of meanings, signs, and values in social life"(Eagleton, 1991). Other than this, ideology may also be very succinctly formulated as "the basis of the social representations shared by members of a group." By this formulation, ideology will enable people, as members of certain group, "to organize the multitude of social beliefs about what is the case, good or bad, right or wrong, for them, and to act accordingly"(van Dijk, 2015). When all this formulation is applied to education, it can evidently be seen that education is a process through which "the production of meaning and values" can be achieved. Up to this point, ideology and education play complimentary and cyclical roles, namely ideology determines the model, type and orientation of education; and at the same time education functions as leg for certain ideology.

In general terms, Indonesian Islam is not a monolithic context. It manifests in several orientations, ranging from moderate, radical to liberal. Mainstream groups such Muhammadiyah and Nahdlatul Ulama' (NU) remain at the axis of moderatism within Indonesian Islam, although within both groups some competing orientations can certainly be found, both radical and liberal. Within this moderate stand, the emergence of competing orientations is sociologically possible, as moderate position is a middle way which can be 
easily directed towards "right" or "left" depending on sociological factors conditioning respective groups. However, despite this fact, mainstream Indonesian Islam is still largely portrayed as moderate. As a consequence, for a relatively long period, reference to Islam in Indonesia is mainly made to mainstream Islamic movements such as Muhammadiyah (established in 1912) and Nahdlatul Ulama' (established in 1926). These two movements, despite their wide spread and mass-following across the country and beyond, are also known for their representation of modern-urban audience and traditional-rural audience, respectively. In addition, they offer non-extremist understanding of Islam which accommodate indigenous and foreign elements in the practice of Islam, although with varied degree.

Being featured as the home for moderate Islam, however, post-New Order Indonesia witnessed the emergence of competing ideologies. These ideologies were suppressed during Suharto's reign which only prevented these competing orientations of Islam from being publicly expressed. The new political situation, nevertheless, has made Indonesian Islam not only ideologically varied, but also politically diverse, as those competing groups have also created ideological rivalry in social and political realm. In this relation, among the most important development is the emergence of non-mainstream Islamic movements. These groups include the Tarbiyah movement which closely related to Partai Keadilan Sejahtera (PKS), Hizbut Tahrir Indonesia (HTI) and its students movement, Front Pembela Islam (FPI), the Salafi groups and other movements which share similar ideology and visions on Islam. ${ }^{1}$

In spreading their ideologies, these movements take variety of medium from informal, non-formal study circles to political party and physical jihad. The Tarbiyah is one of the most popular movements among university student circles. The formation of ideology for the followers and members of these movements took place through regular meetings technically called liqa', dawrah, usrah, or pengajian. Following the popularity of such movements, contemporary

1 The meaning of Salafi might be used in great variation by scholars. In current Indonesian setting, I believe that there are at least three meaning of salafi is being used. First, in general term, salafi is used to refer to groups believe in the doctrine of returning the Qur'an and Sunna which indicate the reference to the earliest generation Muslims. Secondly, for a relative long period, the term "salafi" is also used to designate those who are educated in traditional type of pesantren. In previous decade, therefore, many traditional pesantren affiliated to Nahdlatul Ulama' is referred to as pesantren salafi. Lastly, Salafi is used to refer to specific group that campaign for specific type of understanding of Islam. In other words, Salafi is used as a name of a group. 
Indonesia is also witnessing the growing number of Islamic knowledge seekers not only among students but also general public. In terms of education, those Islamic knowledge seekers are usually coming from non-religious background, and it is often metaphorically said that this has made them as empty glasses filled with water. The consequence is that whatever kinds and colours of water poured into the glasses will certainly determine the colour of the glasses. This is the case with Islamist movements, both among students and general public. Their religious orientations and attitudes are mostly determined by the source of Islamic knowledge which they learned from. In general case, even those who are considered as resource person by these Islamic knowledge seekers are also from non-religious backgrounds who perceive Islam in very simplistic way.

More importantly, a note on the source of Islamic knowledge should also be made. The curiosity in Islamic knowledge combined with close-mindedness and aggressive penetration of information technology have revolutionarily transformed the nature of religious authority in Indonesia. As obtaining information on religious matters is getting much easier, those who are trained in religious knowledge are now less respected and followed than any unidentified information spread among social media and internet (Hosen, 2008) .

Closely related to this phenomenon is the unprecedented growing sectarianism level among Muslim groups. Currently, some Muslim groups are easily trapped into claim of truth to the belief, doctrines and system of thought which they adhere and struggle for; and at the same time, show tendency to claim other beliefs and doctrines as false or invalid. As an example, the antiShi'a sentiment now widespread among most Muslim groups in Indonesia. The dissemination of anti-Shi'a campaigns are done through internet, social media, printed media as well as religious circles such as khutbah (sermons) and pengajian (informal religious classes). Within this situation, there are also some minor groups that campaign for a more tolerant and peaceful Islam, arguing that difference in orientations and thought among Muslims are part of human life dynamic and therefore it should not be taken as a pretext for any exclusion and discrimination. However, groups campaigning for tolerance and peace are becoming increasingly unpopular. Rather than attaining support and attention, in most cases, they are harshly accused as part of liberal Muslims, unbelievers, spoiler of Islam and proponent of western ideology. Furthermore, in many cases, such campaign also fruited in public hatred to those who favour for openmindedness in practicing Islam. Such hatred is not only showed by general and lay Muslims, but also by authority holders, both religious and governmental. 
As just recently happened, the mayor of Bogor in West Java issued a letter prohibiting Shi' ite community in Bogor to commemorate the Ashura which is known as part of Shi' 'ite rituals (Tempo, 2015). Same attitude is also shown by religious authorities. Majelis Ulama' Indonesia (MUI) which is seen as the official holder of Islamic religious authority in Indonesia repeatedly affirmed their sectarian attitude towards issues related to Shi'a in Indonesia. Similarly, although formally Muhammadiyah and NU do not show hostile attitude towards Shi'a, certain groups within both organization sporadically produced hatred to this minority group.

Understanding this background is fundamental in order to draw maps of contemporary dynamics of Indonesian Islam, especially in its relations to models and orientations of Islamic education developed in this multicultural and pluralistic nation; and how Middle Eastern elements influence all this situation, both in context of Indonesian Islam in general, and in Islamic education, in particular. In order to achieve this goal, in the following sections, I will discuss the nature of education developed by Muhammadiyah, Nahdlatul Ulama' and Islamist group, by taking PKS and its Tarbiyah movement as cases studies.

\section{Results and Discussion}

\section{The Transmission of Reform in Education}

Muhammadiyah is an Islamic organization known for its modern inclination. Founded in Yogyakarta in the beginning of twentieth century, it is aimed at purifying, modernising and rationalising religious and social life of Javanese society under Dutch colonialism. Therefore, this movement is sociologically rooted in local conditions. However, although its emergence is basically a response posed by Ahmad Dahlan, the founding father of Muhammadiyah, to local phenomenon; it is not completely void from foreign elements especially that of Middle Eastern as the centre of Islamic knowledge. It can be claimed that the factors which triggered the foundation of Muhammadiyah as a modern Islamic organization are multi-layered. In addition to the problem of syncretism of Islamic teachings and local cultures and religious fanaticism widespread among Indonesian Muslims, a fundamental factor leading to establishment of Muhammadiyah is the problem of backwardness which, among many other factors, is caused by the practice of dualism in education. As Karel Steenbrink shows, in the late nineteenth century, dualism in education 
marked the nature of education in Indonesia (Steenbrink, 1995). This situation is closely related to the Dutch colonialism policy which practiced the politics of divide et impera. This principle is manifested in many fields of Indonesian people's life from social stratifications, legal provision to policy on education. In the field of law, as an example, the Dutch colonial administration classified legal provisions into at least three categories, namely legal provision for Europeans, legal provisions for Arabs and Chinese, and legal provisions for the indigenous of Netherlands Indies.

In educational sector, this discriminative policy is manifested in the establishment of modern and segregated Dutch-modelled education. The Dutch education system is exclusively privileged for children of Dutch officials and children of indigenous people who maintained close ties with Dutch officials and were loyal to them. Not only social class which was marked the discriminatory nature of Dutch education, but also the orientation and curricula. This model of education taught secular subjects and did not pay any attention and give portion to religious education. On the other hand, those who are socially marginalised, economically unpriviliged and did not maintain any ties with Dutch colonial administration were excluded from Dutch education system. Alternatively, those who are from lower social classes were educated in traditional educational institutions, popularly known as pesantren. In the modern day, these two distinct models of education are known as sekolah and pesantren.

Consequently, diametrical contrast between these two models of education can evidently be seen. While Dutch-modelled education is "secularly" oriented, traditional education developed by Indonesian religious leaders was heavily religious and close-minded. Against the backdrop of colonial administration which to some extent was also seen as an endeavour to propagate Christianity in Indonesia, it is understandable that those religious leaders were hostile to the Dutch. As a result, they become internally defensive to all kinds of perceived potential threat to Islam. Furthermore, the implementation of this attitude within the context of education is that traditional educational system taught only religious-related subjects and avoided all other subjects which generally labelled as secular. In turn, traditional Islamic education produced only closeminded alumni who were reluctant to deal with any kinds of change within Indonesian Muslim society.

Amidst this contrast, Ahmad Dahlan offered his synthetical thought and experiment. Therefore, in general term, it is historically accepted that the 
initial reform in Islamic education can be traced to attempts carried out by Ahmad Dahlan. Facing this dualism in education, Ahmad Dahlan sought to synthesize these two models by developing what later known Sistem Pendidikan Muhammadiyah or Muhammadiyah Education System. By this, it is projected that Muhammadiyah's education will put emphasis both on religious and secular subjects in proportional weigh. Historically, religious subjects were taught by Ahmad Dahlan himself, while general subjects were taught by a government-affiliated teacher who voluntarily helped Dahlan to run his school (Yusuf, 2008).

In this context, the influence of Middle Eastern elements within the reform of Islamic education carried out by Ahmad Dahlan can be possibly located. Among the most possible elements is educational reforms pioneered by Muhammad Abduh in Egypt. In her study on relation between Muhammadiyah and Muhammad Abduh's thought, Arbiyah Lubis shows that Muhammadiyah theological thought is influenced by Muhammad Abduh's theological stance (Lubis, 1993). However, the influence of Abduh's thought on Muhammadiyah is basically not confined to theological realm, but also in the field of education. Abduh is critical to traditional model education which put emphasis on memorizing the subject which was practiced since the elementary level of kuttab system up to university level. Alternatively, Abduh opined that memory system should be replaced by insight and comprehension. In Muhammadiyah case, the most important element of Middle Eastern influence within its educational establishment is the model and spirit of reform in Islamic education. Abduh believed that education is the key for reform of society. Therefore, any kinds of reforms should be embarked from reformation of education. As an example, in responding the ill-practiced Islamic law within the context of Egyptian society, Abduh maintained that law can only be properly revised if citizens are educated (Armajani, 2012). Furthermore, Abduh's program of educational reform cannot be grasped separately without taking the idea of ijtihad in Islamic law into account. According to Muhammad Abduh: "religious education had to teach ijtihad through critical examination of the primary source of religion; and it had to include mathematics, the science and comparative history as a vehicle for a well-rounded understanding of the implications of juristic judgement" (Gesink, 2014).

Muhammadiyah system of education resembles Abduh reform program in which it gives place to reason and accommodate non-religious subjects. Benda notes that one of the most important successful achievements of 
Muhammadiyah movement is education (Benda, 1980). Muhammadiyah education teaches modern syllabus which successfully combines religious and non-religious elements (Swe, 2016). As has been indicated earlier, educational system run by Muslim groups in Indonesia is largely dependent on the ideology embraced by respective group. In this context, education also serves as leg for its ideology. Rational inclination and the combination of variety of subject in Islamic education developed by Muhammadiyah is fundamentally in line with its advocacy for ijtihad which again, reflects Abduh's thought on reform on Islamic law.

In a more technical term, Muhammadiyah's education system has attempted to develop both sekolah and madrasa or pesantren types of education. In an Indonesian context, sekolah refers to a system of education which is broadly connected to secular system and subjects, while madrasa as widely known in any other Muslim world, as a system of religious education. Other than madrasa, another type of religious education is also known as pesantren, which according to Van Bruinessen is identified as Indonesian version of madrasa (van Bruinessen, 2008). In its later development, however, Muhammadiyah seems to fail to synthesize these two models, as Muhammadiyah is much more associated with sekolah model rather than madrasa and pesantren models. In other words, Muhammadiyah becomes more exposed to secular-type of education rather than madrasa and or pesantren. Consequently, Muhammadiyah has been criticised of experiencing the lack of ulama' (religious scholars).

It is highly possible that awareness on the imbalance in its educational system, which was previously designed to be balanced, which recently motivated Muhammadiyah to pay more attention to pesantren education. This new trend is resulted in the establishment of a number of pesantren within Muhammadiyah which technically known as "Muhammadiyah Boarding School" (MBS). Regarding this, how far and effective this new direction will transform Muhammadiyah education is a question which need considerably long period to answer. But, if this trend is successful in transforming Muhammadiyah education, another wave of Middle East impacts will certainly take place in Muhammadiyah context. This is possible as in running pesantren, Muhammadiyah will mostly take benefit from those who are graduated from Middle Eastern universities. This possible influx of Middle Eastern graduates into Muhammadiyah education will surely bring impacts to transform the face of Muhammadiyah education in the future. 


\section{Education and the Preservation of Tradition}

Other than Muhammadiyah, Islamic education in Indonesia is also run by Nahdlatul Ulama', an Islamic organization which is largely associated with traditionalism and its inclination to preserve elements of tradition within its religious practices, under the banner of Ma'arif education (Rochmat, 2016). As with Muhammadiyah's case, the foundation of NU is also related to both local and foreign factors. Locally, the penetration of modernist Islamic movements advocated by Muhammadiyah and other similarly-oriented organizations such as Persatuan Islam and al-Irsyad, have been responded by kiais (religious clerics mostly based in pesantren) by institutionalizing traditional Islam which culminated in the foundation of Nahdlatul Ulama'. The term itself literally means the awakening of ulama' (religious scholars) which only strengthens the impression of tensions between the wave of modernisation and traditional ulama's stance. In this context, therefore, pesantren education is a medium through which traditional Islamic practices and values are institutionalized. Furthermore, a fact often quoted to legitimize this goal is related to the attitude that Hasyim Asy'ari, the founding father of NU, showed to Muhammad Abduh. It is mentioned that Asy'ari was an admirer of Abduh's thought especially his thought expressed in al-Manar, but Asy'ari forbid his pupils to read this exegesis not because of Abduh's rational approach to religion, but rather because of Abduh's humiliation of traditional ulama' (van Bruinessen, 2012).

Generally, pesantren education is mostly associated with NU. Historically speaking, the early existence of pesantren in Nusantara is often associated to Maulana Malik Ibrahim, a figure which is believed as the spreader of Islam to Indonesian archipelago. Ibrahim is seen as the first generation of ulama' who pioneered the pesantren system which followed by Raden Rahmat who later popularly known as Sunan Ampel, since he resided in a place called Ampeldenta and conducted Islamic religious classes within this area (Soebahar, 2013). It is not clear from this, nevertheless, whether pesantren is an educational system which resembled Middle Eastern model or locally grown. Robert W Hefner argues that the influence of Middle Eastern style of Islamic education did not take place simultaneously with the coming of Islam to Indonesia, but rather it is result of ceaseless changes and transformation (Hefner, 2008). Hefner's position with regard to the history of Islamic education in Indonesia is partly a criticism of Clifford Geertz's metaphor of "old wine in a new bottle" to describe the Hindu-Buddhist legacy which is merely adopted under the banner of Islam. Similarly, Bruinessen is also of the opinion that pesantren in Indonesia is result 
of long interactions and transformations. In his words:

Rather than imitating Hindu and Buddhist precursors, these late nineteenth-and early twentieth-century pesantrens appeared to be modelled on institutions with which their founders had become familiar during their studies in Arabia: the study circles (halqa) in the Great Mosque of Mecca (the Masjid al-Haram), Cairo's Azhar, which had a dormitory assigned to Southeast Asian students (the riwaq al-Jawa), and especially the slightly modernised madrasas in Mecca at the time. The most prominent of the latter was the Madrasa Sawlatiyya, which was established by Indian Muslims in 1874 and which also attracted many Indonesian students. In 1934, following an incident in which their national pride was impaired, the Indonesians abandoned this madrasa and founded their own school, Dar al-Ulum al-Diniyya, which exists to this very day and has been a major centre of orientation for the Indonesian traditional ulama (van Bruinessen, 2008).

Although scholar such as Bruinessen tends to relate the pesantren tradition with Middle Eastern model, some opinions, as can be summarised from Soebahar's explanation, tends to relate pesantren as combination of local and foreign elements. Dhofier argues that pesantren in Indonesia is resulted from combination of madrasa and tarekat activities (Dhofier, 2011). Whether or not the pesantren as an institution is influenced by Middle Eastern elements, it does not mean that Middle Eastern influence is absent from Nahdlatul Ulama's educational dynamics. The most visible element of Middle Eastern in pesantren education is the pervasive use of Arabic source in teaching. This fact is referred to by Bruinessen as uniqueness of pesantren education system. On the one hand, it is deeply rooted in local values, practices and culture; but on the other, it is also internationally oriented, especially to Mecca (van Bruinessen, 2012).

In traditional pesantren system, teaching activities are mostly carried out by reading a number of books called kitab kuning. Literally, kitab kuning means yellow books which refer to the colour of the paper on which books are printed. Those books are written by ulama' from the Middle Eastern in Arabic which also known as kitab klasik or classical book. In more technical term, they are called al-kutub al-mu'tabara. The reference to these kinds of book is integral part of pesantren education. Soebahar identifies that the only school of law adopted and referred by pesantren is Shafi' ite school of law (Soebahar, 2013). Mujamil Qomar lists some of kitab kuning popularly used in pesantren ranging from figh (Islamic 
jurisprudence), hadith (prophetic tradition), ushul figh (philosophy of Islamic law), to tafsir (exegesis of the Qur'an). In the field of Islamic jurisprudence, as an example, the most popular references used include: Safinah al-Najah, Sullam al-Taufiq, Masail al-Sittin, Mukhtashar, Minhaj al-Qawim, al-Hawasyi al-Madaniyah, al-Risalah, Fath al-Qarib, al-Iqna', Tuhfat al-Habib, al-Muharrar, Minhaj al-Thalibin, Fath al-Wahab, and Tuhfat al-Muhtaj. In the field of Arabic grammar, the books used are: Muqaddimah al-Ajurumiyah, Mutammimah, al-Fawaqih al-Janniyyah, alDhurrah al-Bahiyyah, al-Awamil al-Mi'at, Inna Awla, Alfiyah, Minhaj al-Masalik, Thamrin al-Tullab, al-Rafiyyah, Qathr al-Nada, Mujib al-Nida' and al-Mishbah. In the field of ushul al-din (the fundamentals of religion), can be found such books as: Bahjat al-Ulum, Umm al-Barahin, al-Mufid, Fath al-Mubin, Kifayat al-Awwam, alMiftah fi Syarh al-Ma'rifat al-Islam, and Jawharat al-Tawhid (Qomar, 2006).

The use of kitab kuning which mostly -if not entirely-written by Middle Eastern ulama' also underlines a point on religious authority transmitted from the Arab world to Indonesia. Therefore, it can be asserted that Middle Eastern impacts on Indonesian Islamic education are related to religious authority. The case of authority transmission can also be seen from the case of fatwa. In his classifications of fatwa, Kaptein (2004) lists a category called "traditional fatwa". This refers to a mechanism of fatwa-issuing by ulama' resided in Mecca responding questions raised by Muslims in Indonesia. Although it seems does not directly relate to education, it basically reflects the impact of Middle Eastern authority in education circles. Fatwa-making is an activity which involves kiai as the holder of religious authority, and since kiai is the sole-authority holder in a pesantren as an Islamic educational institution, this fact can still be analysed within the issue of education. Furthermore, this fact is a confirmation of the influence of Middle Eastern elements in traditional Islamic education system in Indonesia. As Azyumardi Azra's study shows, the connection of ulama in Nusantara and ulama in the Middle East was very much intensified (Azra, 2013). While slightly criticizes Azra's finding, Zamakhsyari Dhofier argues that some development in the Middle East, including the opening of Suez Canal, has made connections between Nusantara and the Middle East more accessible which brought consequence of transmission of ideas and knowledge become more intense (Dhofier, 2012).

Apart from this context, a brief note on recent transformation within NU's context of education is worthy. In contrast to Muhammadiyah's case discussed above; has long been associated with pesantren education, Nahdlatul Ulama' is currently transforming its educational system. While pesantren still 
constitutes core and main characteristic of NU's education system, it starts to orient its education into universities which basically suggests NU's inclination into a more modern system of education. However, how this will change future face of NU education and how this phenomenon will bring impacts to the influence of Middle Eastern elements within NU's traditional education is a question which can only be answered in the following decades.

In summary, it can be maintained that the influence of Middle Eastern elements within the practice of education within the context of NU take the form of reference in traditional Islamic studies. This nature has influenced and is in line with NU's attitude towards tradition as well as its methodological position within the context of Islamic legal thought. Legally speaking, in contrast position to Muhammadiyah which advocates for the performing of ijtihad, NU adopts taqlid (imitation or following the teaching of specific school of law, or madzhab) as part of its legal position. In such a case, transmitting Middle Eastern knowledge through reference to kitab kuning is on par with the principle of Islam Bermadzhab and taqlid believed and adhered by NU.

\section{Education and Political Ideology}

As has been indicated earlier, one of important socio-religious phenomena in the post-New Order period is the emergence of Islamist groups. Among many groups, the most prominent is PKS and HTI. For a practical reason, this section will only discuss the influence of Middle Eastern elements within the context of PKS education system. As a political party, PKS is started from student propagation movements in many campus across Indonesia. Many studies, such as by Yon Mahmudi, show that in 1980s, Indonesian Islam witnessed a resurgent in tendency of Islamisation which gave rise to the emergence of Gerakan Tarbiyah (Mahmudi, 2008). Mahmudi reveals that members of Gerakan Tarbiyah were successful in gaining support from students of University of Indonesia which eventually elevated those Tarbiyah activists into the leadership of student government.

The transformation of Gerakan Tarbiyah into a political party took place in the post-Suharto period which was featured by a freedom of speech and expressions. In addition, Gerakan Tarbiyah also transformed into a student organization named Kesatuan Aksi Mahasiswa Muslim Indonesia (KAMMI) in Malang in 1998. KAMMI successfully attracted huge mass-following among students which in turn become the backbone of Partai Keadilan Sejahtera. 
Mahmudi argues that this success is due to accommodative attitude of Gerakan Tarbiyah which is able to accomodate people from diverse background. While some scholars tend to see Gerakan Tarbiyah as a distinct and separated phenomenon of Islamization (Damanik, 2000; Azizm 1995; Azra, 1999), Machmudi believes that the phenomenon of Gerakan Tarbiyah is basically continuation of the process or trend of Islamization in 1970s.

Although the rise of this new santri group is a local phenomenon, it cannot be separated from international influence, especially that of Middle Eastern. Gerakan Tarbiyah and PKS members are mostly influenced and inspired by the teachings of Hasan al-Banna and Ikhwanul Muslimin in Egypt. The adoption of Islam as a sole ideology in dealing with any issues marks one of the most important feature of PKS. This tendency is what is theoretically called as Islamism. Greg Fealy and Anthony Bubalo identify that Islamism is a movement which view Islam as an ideology, that Islam is a religion which encompasses all dimensions of modern society. In the view of Islamists, Islam is a determinant factor in defining all dimensions of life within particular society from governance, education, system of law, to economy and culture. The other element of Islamism is activism (Fealy \& Bubalo, 2007).

The success of PKS or Gerakan Tarbiyah in attracting huge following from students cannot be separated from the system of education they adopt. In the case of PKS, the recruitment of members which is more popularly known as "kader" can be performed individually (fardi) or collectively (jama'i). Analysing PKS case, it can be asserted that the Middle Eastern elements are very influential in shaping its mode of thought. Not only education, political issues and stance of Ikhwan al-Muslimin (Muslim Brotherhood) in Egypt strongly determine PKS position. More importantly, education and politics are two unseparated activities within the context of PKS. In contrast to Muhammadiyah and NU which much more open in conducting their training for its member, PKS is much more exclusive. It develops both formal and informal types of education. In general context, formal education is run for kindergarten and primary level, while for university-student level the education take out of informal organization. In most cases, the education and or training for this age-group take place in the mosques or the murabbi's houses. Murabbi (male) and murabbiyah (female) are those who are appointed by the mechanism of organization to supervise, guide and teach circles, classes or any meetings regularly conducted by the groups.

The Middle Eastern influence to PKS is particularly from the Ikhwanul Muslimin (Muslim Brotherhood) ideology. As Rahmat (2009) records, the 
influence of Ikhwanul Muslimin is pervasive as ideology of this movement has been indoctrinated long-before the foundation of PKS through Lembaga Dakwah Kampus (Campus Propagation Movements). The model of education offerred by PKS to university students are mostly non-formal and informal. But, in late decade, PKS started to embark on running formal education system by founding kindergarten and elementary schools in many places in Indonesia.

\section{Conclusion}

From three groups with which three different ideologies are examined in this paper, it can be concluded that although they come from the same regional source, they take various forms when coming to Indonesia. From a modernist point of view as represented by Muhammadiyah, this Middle Eastern model is taken not only for education but also for a more fundamental purpose, namely supporting its ideology and agenda. The doctrine is non-conformism to any schools of law in the Islamic legal context. This non-conformism orientation is manifested in Muhammadiyah's campaign for ijtihad, resisting the earlier period claim of the shut of the ijtihad gate. Not limited to a modernist group, the Middle Eastern connection with the Indonesian context can also be identified from the traditional group; in this case, Nahdlatul Ulama' exhibits a unique point. It has smoothly combined a pesantren education, a locally grown institution, with that of Middle Eastern content through the adoption of Kitab Kuning. Although pesantren has currently been undergoing adaptation and reform, its curricula' core element is still heavily loaded with Middle Eastern ingredients. Lastly, different from the last two groups, which are more moderate in orientation, Middle Eastern elements also influenced Islamist groups such as Partai Keadilan Sejahtera. The form of movement and organization it took are sole-mirror of institution and organization developed in the Middle East. The same situation can also be seen in terms of the schedule. Despite that Islamist group such as PKS grows in Indonesian soil, their attachment to Middle Easternoriginated issues is more visible than local problems in Indonesia.

\section{References}

Armajani, J. (2012). Modern Islamist movement: History, religion and politics. Oxford: Wiley-Blackwell.

Aziz, A. (1995). Meraih kesempatan dalam situasi mengambang: Studi kasus kelompok keagamaan mahasiswa Univesitas Indonesia. Penamas: Jurnal 
Penelitian Agama dan Masyarakat, 20(7), 1-17.

Azra, A. (1999). Kelompok sempalan di kalangan mahasiswa PTU: Anatomi sosio historis" in Dinamika Islam di perguruan tinggi wacana tentang pendidikan agama Islam. Jakarta: Logos, 233-246.

Azra, A. (2013). Jaringan ulama Timur Tengah dan kepulauan nusantara abad XVII Eु XVIII: Akar pembaruan Islam Indonesia. Jakarta: Prenada Media.

Benda, H. J. (1980). The crescent and the rising sun: Indonesian Islam under the Japanese occupation 1942-1945. Jakarta: Pustaka Kaya.

Damanik, A. S. (2000). Fenomena Partai Keadilan. Jakarta: Teraju.

Dhofier, Z. (2011). Tradisi pesantren: Studi pandangan hidup kyai dan visinya mengenai masa depan Indonesia. Jakarta: LP3ES.

Eagleton, T. (1994). Ideology. New York: Routledge.

Fealy, G. \& Bubalo, A. (2007). Jejak kafilah: Pengaruh radikalisme Timur Tengah di Indonesia. Bandung: Mizan.

Gesink, I. F. (2014). Islamic educational reform in nineteenth-century Egypt: Lesson for the present, in Tan. C. (ed). Reforms in Islamic education: International perspectives. London: Bloomsbury Academic.

Hefner, R. W. (2008). The politics and culture of Islamic education in Southeast Asia, in Hefner, R. W. (ed). Making Muslims modern: The politics of Islamic education in Southeast Asia. Honolulu: University of Hawaii Press.

Hosen, N. (2008). Online fatwa in Indonesia: From fatwa shopping to googling kiai, in Fealy, G. \& White, S. (eds). Expressing Islam: Religious life and politics in Indonesia. Singapore: ISEAS.

Kaptein, N. J. G. (2004). The voice of the 'Ulamâ': Fatwas and religious authority in Indonesia. Singapore: Institute of Southeast Asian Studies.

Lubis, A. (1993). Pemikiran Muhammadiyah dan Muhammad Abduh. Jakarta: Bulan Bintang.

Mahmudi, Y. (2008). Islamising Indonesia: The rise of Jemaah Tarbiyah and prosperous Justice Party. Canberra: ANU Press.

McLellan, D. (2013). Ideology. Kaldis, B. (ed). Encyclopedia of philosophy and the social sciences. Vol. 9 Thousand Oaks, CA: SAGE Publications.

Qomar, M. (2006). Pesantren, dari transformasi metodologi menuju demokratisasi institusi. Jakarta: Erlangga.

Rahmat, I. (2008). Ideologi politik PKS: Dari masjid kampus ke gedung parlemen. 
From the centre to periphery: The Middle Eastern impacts on Islamic education in Indonesia (Pradana Boy ZTF)

Yogyakarta: LKiS.

Rochmat, S. (2016). Dialectical Islamic and confucian traditions within ASEAN to hinder the clash of civilization. Journal of Social Studies (JSS), 12(2).

Soebahar, A. H. (2013). Modernisasi pesantren: Studi transformasi kepemimpinan kiai dan sistem pendidikan pesantren. Yogyakarta: LKiS.

Steenbrink, K. (1995). Kawan dalam pertikaian: Kaum kolonial Belanda dan Islam di Indonesia 1596-1942. Bandung: Mizan.

Swe, Y. L. (2016). THE history of the development of SD Muhammadiyah Kauman Yogyakarta from 1980 to 2015. Journal of Social Studies (JSS), 12(2).

van Bruinessen, M. (2008). Traditionalist and Islamist Pesantren in contemporary Indonesia", in Noor, F. A. et. all (ed), The madrasa in Asia: Political activism and transnational linkage. Amsterdam: Amsterdam University Press.

van Bruinessen, M. (2012). Kitab Kuning, pesantren dan tarekat. Yogyakarta: Gading Publishing.

van Dijk, T. A. (2015). Introduction. Ideology: A multidisciplinary approach. London: SAGE Publications Ltd..

Yusuf, Y. (2008). Introduction, in Hamdan. Paradigma pendidikan Muhammadiyah. Yogyakarta: Ircisod. 
Journal of Social Studies (JSS), Volume 16, Number 1, 2020: 65-82 